\title{
Evaluating the Impact of Seasonal Variability on Groundwater Quality using Multivariate Analysis of Variance
}

\author{
Izinyon, O.C $\quad$ Meindinyo, L.I $\quad$ Ilaboya, I.R \\ Department of Civil Engineering, Faculty of Engineering, PMB 1154, University of Benin, \\ Benin City, Edo State. Nigeria
}

\begin{abstract}
Groundwater which constitutes high percent of the global fresh water is one of the most important sources of drinking water. When polluted, groundwater has deleterious effects on its users. Consequently, the quality and pollution of groundwater is a health concern in the world. The focus of the study is to evaluate the impact of seasonal variation on the quality of groundwater within the study areaHundred (100) boreholes spread to cover the study area were sampled. The water samples were analyzed using standard procedures for assessing drinking water qualities in order to determine the condition of groundwater quality within the study area. Statistical analysis of the groundwater quality data was done using weighted average index method to determine the water quality index and multivariate analysis of variance (MANOVA) to assess the impact of seasonal variation. Result of multivariate analysis of variance (MANOVA) which was employed to assess the presence of seasonal variability revealed that the calculated partial Eta squared of the Pillai's trace statistics was 1.00 which indicates $100 \%$ variability among the dependent variables occasioned by seasonal change.
\end{abstract}

Keywords: Multivariate statistics, Seasonal variation, Water quality index, Pillai's trace statistics and Partial Eta squared.

DOI: $10.7176 / \mathrm{CMR} / 11-10-05$

Publication date: December $31^{\text {st }} 2019$

\section{Introduction}

Water and its quality are a very serious and vital issue for mankind due to its link with human health and welfare. It is one of the most precious and replenishable natural resources. There is abundance of it on the earth surface but the quality as well as the quantity to serve its intended purpose is where the problem lies. The demand for water has increased over the years and this has led to water scarcity in many parts of the world and the situation is aggravated by the problem of water pollution or contamination (Sundara et al., 2010). The application of different multivariate statistical techniques, such as cluster analysis (CA), principal component analysis (PCA) and factor analysis (FA) help identify important components or factors accounting for most of the variances of a system. They are designed to reduce the number of variables to a small number of indices while attempting to preserve the relationships present in the original data (Simeonov, et al., 2003; Simeonov, et al., 2004). (Iyer et al., 2003) constructed a statistical, model which is based on the PCA for coastal water quality data from the Cochin coast in south west India to explain the relationships between the various physicochemical variables that have been monitored and also to evaluate the impact of environmental fluctuations on the coastal water quality.

MANOVA is the multivariate analogue to Hotelling's $\mathrm{T}^{2}$. The purpose of MANOVA is to test whether the vectors of means for the two or more groups are sampled from the same sampling distribution. Just as Hotelling's $\mathrm{T}^{2}$ will provide a measure of the likelihood of picking two random vectors of means out of the same hat, MANOVA gives a measure of the overall likelihood of picking two or more random vectors of means out of the same hat. There are two major situations in which MANOVA is used.

i. The first is when there are several correlated dependent variables, and the researcher desires a single, overall statistical test on this set of variables instead of performing multiple individual tests.

ii. The second, and in some cases, the more important purpose is to explore how independent variables influence some patterning of response on the dependent variables. Here, one literally uses an analogue of contrast codes on the dependent variables to test hypotheses about how the independent variables differentially predict the dependent variables.

MANOVA also has the same problems of multiple post hoc comparisons as ANOVA. An ANOVA gives one overall test of the equality of means for several groups for a single variable. The ANOVA will not tell you which groups differ from which other groups. (Of course, with the judicious use of a priori contrast coding, one can overcome this problem.) The MANOVA gives one overall test of the equality of mean vectors for several groups. But it cannot tell you which groups differ from which other groups on their mean vectors. (As with ANOVA, it is also possible to overcome this problem through the use of a priori contrast coding.) In addition, MANOVA will not tell you which variables are responsible for the differences in mean vectors. Again, it is possible to overcome this with proper contrast coding for the dependent variables Shrestha and Kazama, 2007). 


\section{Materials and Methods}

\subsection{Description of study area}

The study area for this research is the Niger Delta Basin Development Authority. This study covers the original area of operation of the River Basin Authority, which is Rivers and Bayelsa State alone. The geographical coordinates of Rivers and Bayelsa states are $4.8581^{\circ} \mathrm{N}$ and $6.9209^{\circ} \mathrm{E}$ and $4.25^{\circ} \mathrm{S}$ and $5.37^{\circ} \mathrm{W}$ and $6.75^{\circ} \mathrm{E}$ respectively (Nwankwoala et al., 2011). The Niger Delta Basin is situated in the south-south geo-political zone of Nigeria. It is located in the rain forest region with relative humidity above $80 \%$ having an annual temperature range of $25^{\circ} \mathrm{C}$ to $31^{\circ} \mathrm{C}$ and annual rainfall of $4700 \mathrm{~mm}$ on the coast to about $2400 \mathrm{~mm}$. The basin is characterized by two alternating climatic conditions of a long period of rainy season spanning from March to November, followed by a dry season spreading from November to March (Nwankwoala, et al., 2011). Figures 1 and 2 shows the Google earth and the study area maps respectively.

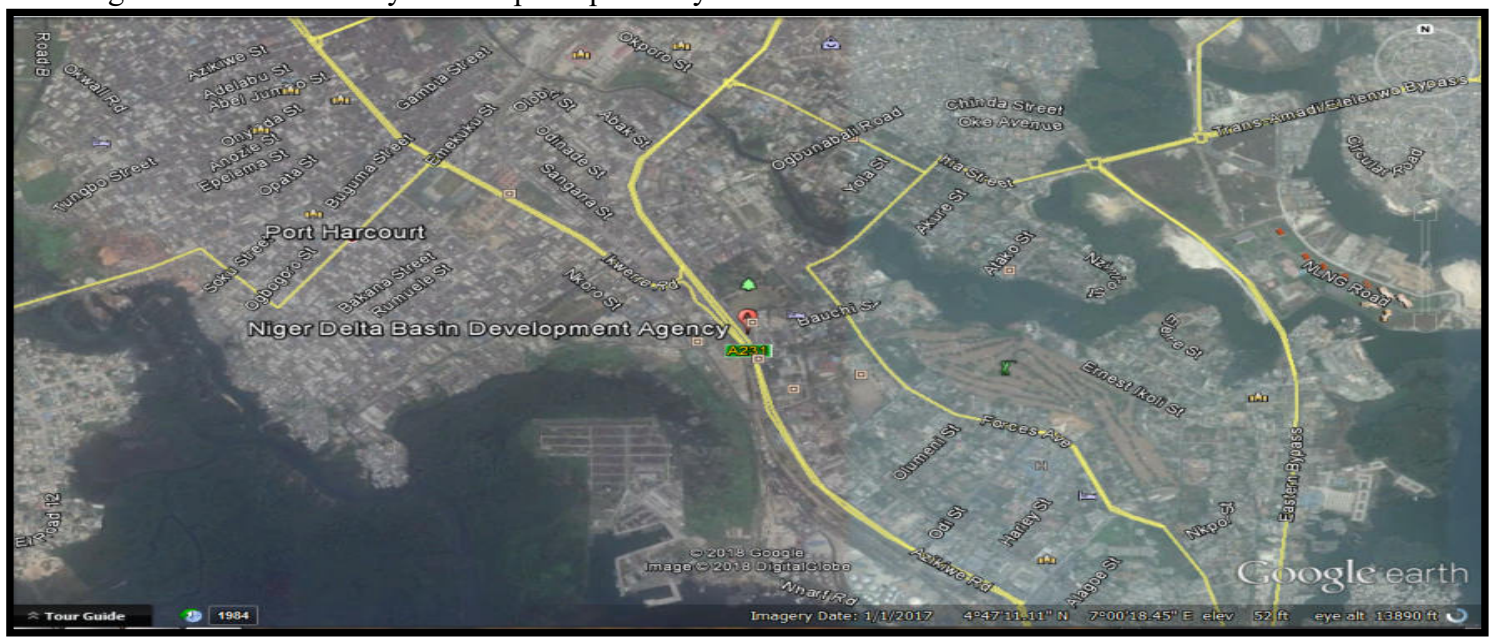

Figure 1: Google earth map of study area (Google .com)

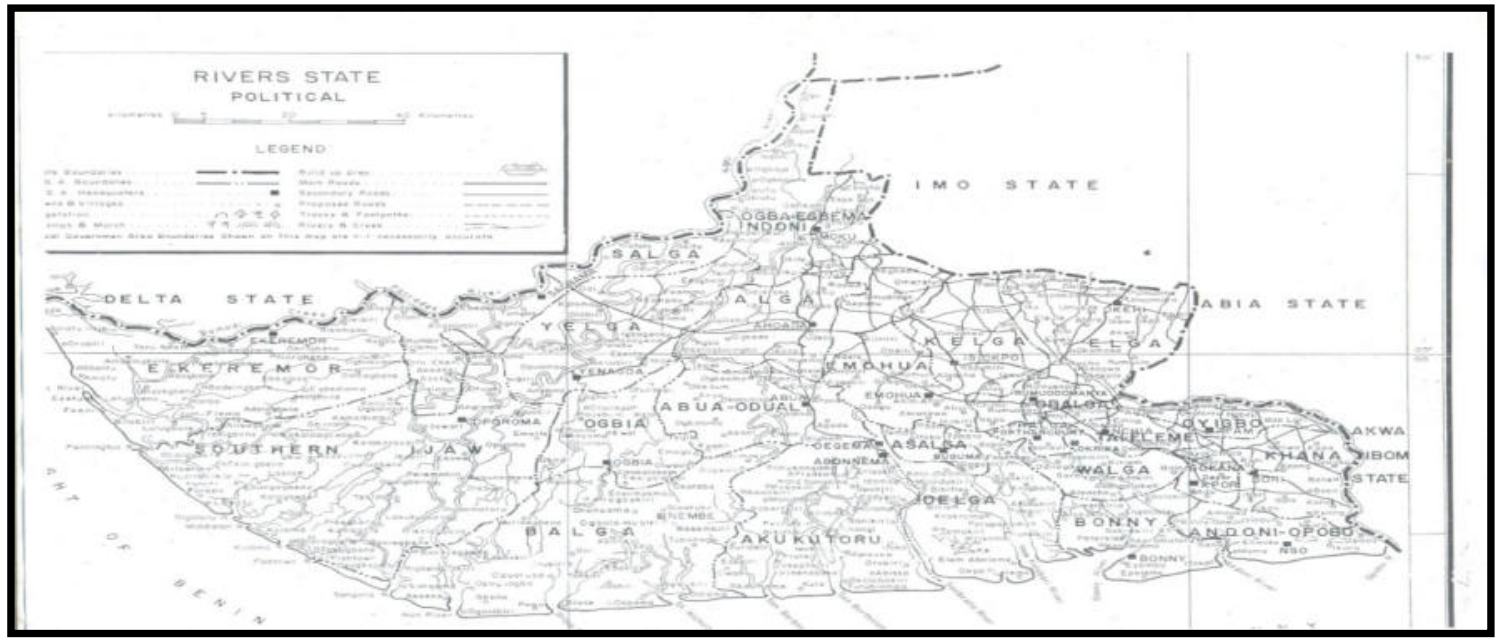

Figure 2: Map of study area ((Bolaji and Tse, 2009)

2.1.1 Geology and Hydrogeology of study area

The Niger Delta Basin is located on the continental margin of the Gulf of Guinea in equatorial West Africa. The Niger Delta lithofacies is made up of the three distinct vertical subdivisions viz. the Benin formation, the Agbada formation and the Akata formation. The Benin formation being the upper delta-top Lithofacies comprises of massive continental sands and gravels. The Agbada formation or facie consists of the pro-delta marine shales, with low stand turbidite fans which are deposited in a deep marine setting. In the Northern Delta Sector during the Oligocene times the Benin formation first occurs (Bolaji and Tse, 2009). Similarly, Paleocene age was established as the occurrence of the Akata formation in the proximal parts of the Delta. The Niger Delta complex geomorphologic features comprise of fresh water swamps, mangrove swamps, beaches, bars, and estuaries (Bolaji and Tse, 2009). 


\subsection{Sampling location and sample collection}

The boundary of built up area (land use) within the study area was digitized and gridded at $2 \mathrm{~km}$ interval to determine the sampling points and ensure uniform coverage. Water samples was collected systematically so as to have a general overview of the water quality condition within the study area. For accurate geo-referencing of the selected boreholes, Garmin hand held GPS receiver was employed to determine the geographical coordinates of each borehole. A section of the boreholes sampled including their location and geographical coordinates is presented in Table 1. One hundred (100) boreholes were systematically sampled with reference to location points at each season: Wet season (July to October 2018) and dry season (November to December 2018) in order to determine the physico-chemical and biological parameters of the groundwater samples. At every point of collection, the air tight, clean and dried plastic containers were rinsed two to three times with the borehole water to be sampled before collection. The samples were labelled properly and stored in air tight, clean and dried plastic containers before been transported to Water Resources and Environmental laboratory in the Department of Civil Engineering, University of Benin were the analysis were conducted in line with standard procedures and guideline recommended by World Health Organization (WHO). The water samples were analyzed in triplicates to obtain the mean value and standard deviation of each water quality test parameters. For the analysis of biochemical oxygen demand (BOD), the black bottles containing the water samples remained tightly closed prior to analysis in order to prevent photosynthetic and oxygen generation. In-situ parameters, namely; dissolved oxygen (DO), temperature, $\mathrm{pH}$ electrical conductivity (EC) and total dissolved solids (TDS) were determined in the field immediately after sample collection to avoid false measurement values (APHA, 2005).

Table 1: Coordinate Data of Sampled Boreholes (RIVERS)

\begin{tabular}{|c|c|c|c|}
\hline Borehole Codes & Locations & Northings & Easting \\
\hline 1. Sample R1 & Igbu Ahaoda & 239820 & 561471 \\
\hline 2. Sample R2 & Mini Ama & 269110 & 525361 \\
\hline 3. Sample R3 & Arukwo-Abua & 235669 & 537656 \\
\hline 4. Sample R4 & Bakana & 286341 & 528043 \\
\hline 5. Sample R5 & Edeoha-Ahoada & 237214 & 556600 \\
\hline 6. Sample R6 & Edeoha-Ahoada & 236203 & 556600 \\
\hline 7. Sample R7 & Okoboh-Abua & 235766 & 540433 \\
\hline 8. Sample R8 & Buguma & 262207 & 524264 \\
\hline 9. Sample R9 & Air force Base & 280557 & 534103 \\
\hline 10. Sample R10 & Trans Amadi & 279389 & 530030 \\
\hline 11. Sample R11 & Ipo-Ikwerre & 274121 & 532098 \\
\hline 12. Sample R12 & Woji & 286716 & 533642 \\
\hline 13. Sample R13 & Rumuokwurushi (1) & 283293 & 536010 \\
\hline 14. Sample R14 & Amakiri Polo & 286238 & 527163 \\
\hline 15. Sample R15 & Rukpokwu & 289003 & 534162 \\
\hline 16. Sample R16 & Aggrey & 280451 & 526634 \\
\hline 17. Sample R17 & NDBDA & 278741 & 529397 \\
\hline 18. Sample R18 & Rumuokwurushi (2) & 283012 & 536068 \\
\hline 19. Sample R19 & Amadi-Ama & 279849 & 530118 \\
\hline 20. Sample R20 & Owodu & 287302 & 531219 \\
\hline 21. Sample R21 & Okochiri & 307314 & 519241 \\
\hline 22. Sample R22 & Trans Amadi (3) & 278023 & 530112 \\
\hline 23. Sample R23 & Railway & 279801 & 527029 \\
\hline 24. Sample R24 & Bundu & 279684 & 525973 \\
\hline 25. Sample R25 & Oyorokoto & 325714 & 496236 \\
\hline 26. Sample R26 & Kono Town & 334047 & 508598 \\
\hline 27. Sample R27 & Oyigbo (1) & 289245 & 538032 \\
\hline 28. Sample R28 & Ngo Town Andoni & 323819 & 495804 \\
\hline 29. Sample R29 & Yegha Gokona & 319044 & 517018 \\
\hline 30. Sample R30 & Oyigbo (2) & 289599 & 538240 \\
\hline 31. Sample R31 & Nyokuru & 339050 & 510170 \\
\hline 32. Sample R32 & Tegu-Gokana & 316831 & 519746 \\
\hline 33. Sample R33 & Woji (2) & 286421 & 533116 \\
\hline
\end{tabular}

\subsection{Water Quality Analysis}

A total of thirty-three (33) physico-chemical parameters and two (2) microbiological parameters were analyzed for each sampled domestic borehole to provide an insight into the overall quality of water within the study area. The physico-chemical parameters include: temperature, odour, colour/clarity, total hydrocarbon content (THC), 
pH, Electrical conductivity (EC), Turbidity, Total suspended solid (TSS), Salinity, Alkalinity, Total Dissolve Solids (TDS), and Dissolved Oxygen (DO). Others are; Biochemical Oxygen Demand (BOD), Chemical Oxygen Demand (COD), Bicarbonate $\left(\mathrm{HCO}_{3}\right)$, Sodium $(\mathrm{Na})$, Potassium $(\mathrm{K})$, Calcium(Ca), Magnesium $(\mathrm{Mg}), \mathrm{Chloride}\left(\mathrm{Cl}^{-}\right.$ ), Phosphorus (P), Ammonium $\left(\mathrm{NH}_{4}\right)$, Nitrite $\left(\mathrm{NO}_{2}\right)$, Nitrate $\left(\mathrm{NO}_{3}\right)$, Sulphate $\left(\mathrm{SO}_{4}\right)$ and heavy metals, namely; Iron (Fe), Manganese (Mn), Zinc (Zn), Copper (Cu), Chromium (Cr), Cadmium (Cd), Nickel (Ni) and Lead (Pb). The microbiological parameters include: Total Coliform Counts (TCC) and E. Coli

\subsubsection{Determination of in-situ parameters; (pH, EC, TDS, DO and Temperature)}

For electrical conductivity (EC), total dissolved solids (TDS), $\mathrm{pH}$, temperature and dissolved oxygen (DO), in-situ measurements were carried out since the measurement values of the parameter's changes with storage time (WHO, 2003). $\mathrm{pH}$, electrical conductivity, temperature and total dissolved solids were measured using portable meter's (multi-parameters) while dissolved oxygen was examined using DO meter (Lutron DO-5509, Range $0-20 \mathrm{mg} / \mathrm{l}$ ) shown in Figure 3

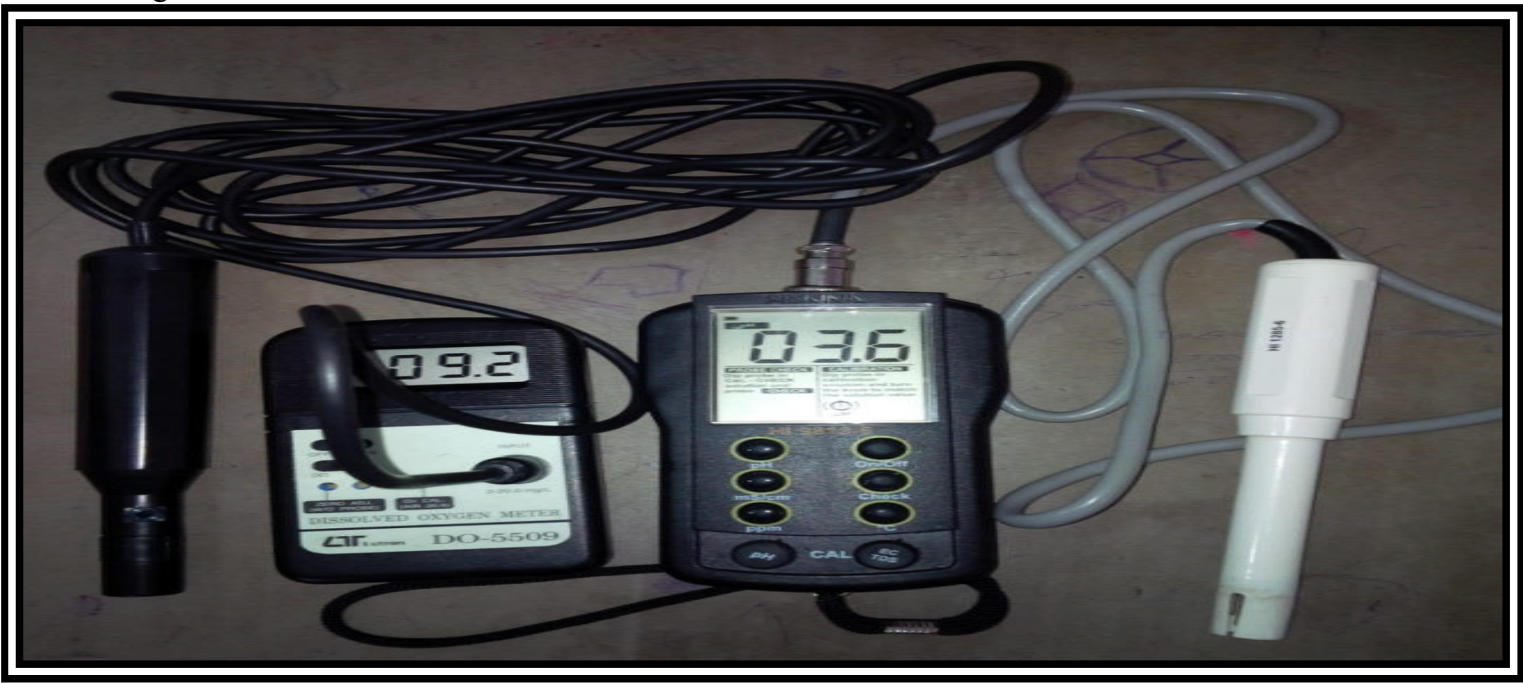

Figure 3: DO meter and multi portable meter

The multi portable meter probe was submerged in the water at $4 \mathrm{~cm}$ and $\mathrm{pH}$ mode selected. Water sample was stirred gently and $\mathrm{pH}$ value displayed on the meter was allowed to adjust and stabilize before recording. Other measurements buttons were pressed successively and values recorded. The procedure was repeated three (3) times and the mean value calculated for each parameter. DO meter was also inserted into the water sample at about $10 \mathrm{~cm}$ depth using the oxygen probe handle.

UNICAM 969 Atomic Absorption Spectrometer (AAS) shown in Figure 4 was used to determine the concentration of heavy metals such as; Iron (Fe), Manganese (Mn), Zinc ( $\mathrm{Zn})$, Copper $(\mathrm{Cu})$, Chromium $(\mathrm{Cr})$, Cadmium (Cd), Nickel (Ni), Lead (Pb), and Vanadium (V) while UV visible spectrophotometer (Thermo Scientific Spectronic $20 \mathrm{D}+$ ) presented in Figure 5 was used to analyzed the level of phosphorous $(\mathrm{P})$, Nitrate $\left(\mathrm{NO}_{3}\right)$, Nitrite $\left(\mathrm{NO}_{2}\right)$ and Sulphate $\left(\mathrm{SO}_{4}\right)$. Other apparatus utilized included $250 \mathrm{ml}$ separating glass funnels, Cuvette, $10 \mathrm{ml}$ and $50 \mathrm{ml}$ pipette, $250 \mathrm{ml}$ conical flask, $50 \mathrm{ml}$ burette, $25 \mathrm{ml}$ and $50 \mathrm{ml}$ volumetric flask, glass beads, refrigerator, oven and whatman filter paper.

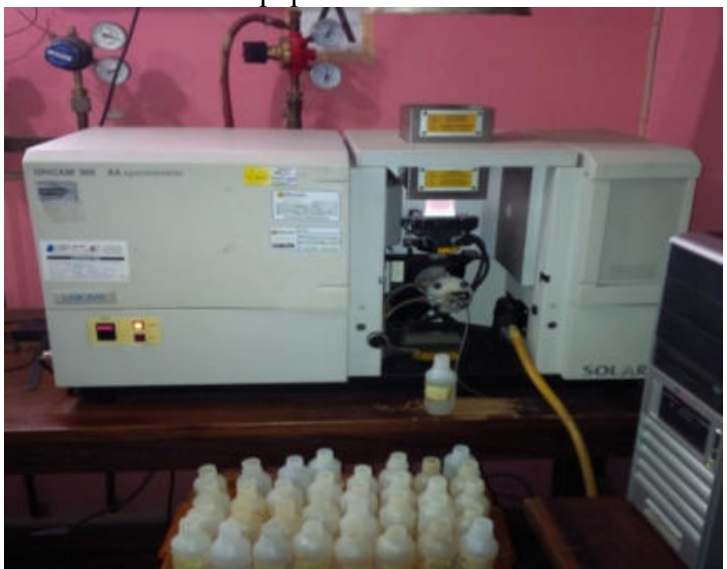

Figure 4: UNICAM 969 AA Spectrometer

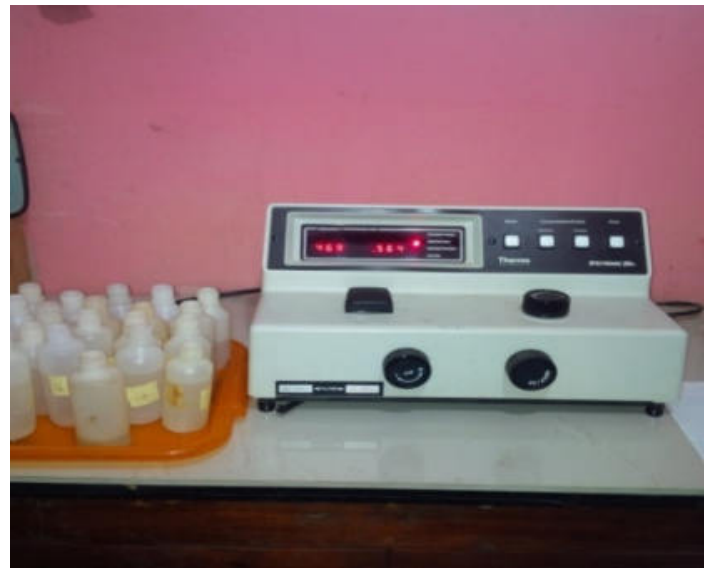

Figure 5: UV Visible Spectrophotometer 
Preparation of reagents and procedures employed in the laboratory for the analysis and determination of all water quality parameters followed the standard methods recommended by relevant authorities such as World Health Organization (WHO).

\subsection{Analysis of seasonal variability using MANOVA}

To study the seasonal variability of the groundwater quality parameters, multivariate analysis of variance (MANOVA) was employed. The following steps were used to justify the presence of seasonal variability in the water quality parameters

\subsubsection{Assessing the suitability of MANOVA based on multivariate outliers}

Multivariate alliance is usually calculated through a measure known as the Mahalanobis constant. If the maximum calculated value of the Mahalanobis constant is less than the critical value, then the assumption of multivariate outliers has not been violated. Therefore, if multivariate outliers have not been violated, then we can investigate the concept of seasonal variability using multivariate analysis of variance (MANOVA) otherwise, we must think of another statistical concept to track the presence of seasonal variability (Alkarkhi, 2008; Shrestha and Kazama, 2007). The critical values of the Mahalanobis constant is presented in Table 2

\section{Table 2: Critical values of Mahalanobis constant}

\begin{tabular}{|c|c|c|}
\hline S/No & Degree of Freedom & Critical Value \\
\hline 1 & 2 & 13.82 \\
\hline 2 & 3 & 16.27 \\
\hline 3 & 4 & 18.47 \\
\hline 4 & 5 & 20.52 \\
\hline 5 & 6 & 22.46 \\
\hline 6 & 7 & 24.32 \\
\hline 7 & 8 & 26.13 \\
\hline 8 & 9 & 27.88 \\
\hline 9 & 10 & 29.59 \\
\hline
\end{tabular}

\subsubsection{Descriptive Statistics}

Descriptive statistics was employed to check the difference in the mean and standard deviation of the sampling group. The mathematical equations for computing the mean and standard deviation are presented as follows.

$\operatorname{Mean}\left(\bar{X}_{),=} \frac{1}{n} \sum_{i=1}^{n} X_{i}\right.$

Standard Deviation $(\mathrm{S})=L(n=1)$
2.4.4 Box Test or Covariance Matrix

$$
\left[\frac{1}{(n=1)} \sum\left(X_{i}-\bar{X}\right)^{2}\right]^{0.5}
$$

In multivariate analysis of variance, we set out to test the null hypothesis that observed covariance matrix of all the dependent variables (water quality parameters) are equal across group (season) that is there is no seasonal variation in the water quality parameters. If the calculated p-value is less than $0.05(\mathrm{p}<0.05)$ we reject the null hypothesis and conclude that the assumption of equal covariance matrices across group has not been satisfied; an indication that seasonal variability exists among the group (Alkarkhi, 2008; Shrestha and Kazama, 2007).

\subsubsection{The Multivariate Test}

Different statistical method for computing the F-value for multivariate analysis of variance exits in literature. One of them is the Roy's largest root which is probably the most acceptable and also the most susceptible to deviation in the covariance matrix. The next is the Pillai's Trace followed by Wilk's Lambda. Pillai's Trace is the least sensitive to the violation of the assumption of covariance matrix. If the p-value of the Pillai's Trace is less than 0.05 then we reject the null hypothesis that the water quality parameters are the same for the two groups and conclude that seasonal variability actually exists (Alkarkhi, 2008; Shrestha and Kazama, 2007).

\subsubsection{Levene's Test of Equality of Error Variance}

If seasonal variability exists, then the calculated error variance for all the dependent variables for the different sampling location must not be the same. To test the null hypothesis that the error variance of the dependent variables is equal across groups, Levene's test of equality of error variance was computed. Since calculated pvalue for most of the dependent variables (groundwater quality parameters) is greater than 0.05 , then, it was concluded that seasonal variability exists among the group (Alkarkhi, 2008; Shrestha and Kazama, 2007). 


\section{Results and Discussion}

\subsection{Analysis of seasonal variability using MANOVA}

Variation in season affects the quality of groundwater. For shallow wells which are highly susceptible to infiltration of anthropogenic impurities, seasonal variation is pivotal to the quality of the water. In the Niger Delta region for example, activities of oil exploration and exploitation can affect the quality of groundwater owing to the porous nature of the soil which allows for speedy infiltration of impurities. To study the effect of seasonal variation, twenty one (21) water quality parameters, namely; $\mathrm{pH}$, Electrical conductivity (EC), Salinity, Total Dissolve Solids (TDS), Dissolved Oxygen (DO), Bicarbonate $\left(\mathrm{HCO}_{3}\right)$, Sodium (Na), Potassium(K), Calcium (Ca), Magnesium $(\mathrm{Mg})$, Chloride $\left(\mathrm{Cl}^{-}\right)$, Phosphate $\left(\mathrm{PO}_{4}\right)$, Nitrate $\left(\mathrm{NO}_{3}\right)$, Sulphate $\left(\mathrm{SO}_{4}\right)$, Iron $(\mathrm{Fe})$, Zinc $(\mathrm{Zn})$, Copper $(\mathrm{Cu})$, Turbidity, Total suspended solid (TSS), Temperature and Alkalinity were monitored using 100 boreholes for wet and dry season. To apply multivariate analysis of variance (MANOVA), in the study of seasonal variability, the following assumptions and conditions were tested.

\subsubsection{Testing the normality assumption of the dependent variables}

For seasonal variability, it is expected that the dependent variables (water quality parameters) varies with season and do not obey normality. In addition, results of the water quality parameters should not contain outliers and the significant value ( $p$-value) computed based on Kolmogorov smirnov and Shapiro-wilk test must be less than 0.05; i.e. $(p<0.05)$ for all the dependent variables. Results of the computed $p$-value based on Kolmogorov smirnov and Shapiro-wilk is presented in Table 3 and 4 while the outlier detection test using box plot is presented in Figure 6 Table 3: Testing the assumption of normality for MANOVA

\begin{tabular}{|c|c|c|c|c|c|c|c|c|c|}
\hline $\begin{array}{l}\text { Tests of Normality } \\
\text { Season = Dry Season } \\
\text { Title }\end{array}$ & - & & & Tests & ormality & & & & \\
\hline 턴 Normal Q-Q Plots & & & & Kolr & row-Sm & & & giro-Wil & \\
\hline $\mathrm{pH}$ & & & Season & Statistic & df & Sig. & Statistic & $d f$ & Sig. \\
\hline Witrate & & $\mathrm{pH}$ & Dry Season & .111 & 100 & .004 & .967 & 100 & .013 \\
\hline Electrical Conductiv & & & Wet Season & .099 & 100 & .018 & .973 & 100 & .037 \\
\hline 僧 Turbidity & & Nitrate & Dry Season & .313 & 100 & .000 & .528 & 100 & .000 \\
\hline Wilif Dissolved Oxygen & & & Wet Season & .111 & 100 & .004 & .962 & 100 & .006 \\
\hline Thilit Total Dissoved Solit & & Electrical Conductivity & Dry Season & .193 & 100 & .000 & .703 & 100 & .000 \\
\hline Wilit Sodium & & & Wet Season & .106 & 100 & .008 & .977 & 100 & .083 \\
\hline hulphate & & Turbidity & Dry Season & .435 & 100 & .000 & .323 & 100 & .000 \\
\hline Lilin Zinc & & & Wet Season & .481 & 100 & .000 & .201 & 100 & .000 \\
\hline Wull Copper & & Dissolved Oxygen & Dry Season & .196 & 100 & .000 & .885 & 100 & .000 \\
\hline Tron Iron & & & Wet Season & .193 & 100 & .000 & .928 & 100 & .000 \\
\hline Carbonate & & Total Dissoved Solids & Dry Season & .251 & 100 & .000 & .591 & 100 & .000 \\
\hline 佯 Total Suspended St & & & Wet Season & .152 & 100 & .000 & .867 & 100 & .000 \\
\hline Ch Phosphate & & Sodium & Dry Season & .147 & 100 & .000 & .916 & 100 & .000 \\
\hline 一䎡 Temperature & & & Wet Season & .134 & 100 & .000 & .817 & 100 & .000 \\
\hline - Wilitit Alkalinity & & Sulphate & Dry Season & .454 & 100 & .000 & .193 & 100 & .000 \\
\hline Walit Salinity & & & Wet Season & .140 & 100 & .000 & .957 & 100 & .003 \\
\hline Thanesium & & Zinc & Dry Season & .205 & 100 & .000 & .897 & 100 & .000 \\
\hline Potassium & & & Wet Season & .097 & 100 & .022 & .965 & 100 & .009 \\
\hline - 国 Detrended Normal $\mathrm{Q}-\mathrm{Q}$ & & Copper & Dry Season & .374 & 100 & .000 & .693 & 100 & .000 \\
\hline 曾 Title & $\Rightarrow$ & & Wet Season & .092 & 100 & .038 & .958 & 100 & .003 \\
\hline 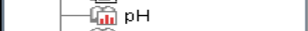 & & Chloride & Dry Season & .084 & 100 & .075 & .970 & 100 & .021 \\
\hline Nith Nitrate & & & Wet Season & .157 & 100 & .000 & .775 & 100 & .000 \\
\hline
\end{tabular}

Table 4: Testing the assumption of normality for MANOVA

\begin{tabular}{|c|c|c|c|c|c|c|c|c|}
\hline 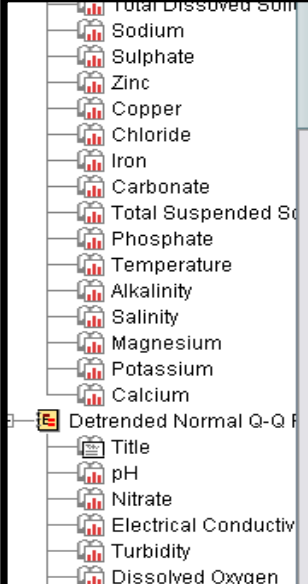 & $\begin{array}{l}\text { Iron } \\
\text { Carbonate } \\
\text { Total Suspended Solids } \\
\text { Phosphate } \\
\text { Temperature } \\
\text { Alkalinity } \\
\text { Salinity } \\
\text { Magnesium } \\
\text { Potassium } \\
\text { Calcium }\end{array}$ & $\begin{array}{l}\text { Dry Season } \\
\text { Wet Season } \\
\text { Dry Season } \\
\text { Wet Season } \\
\text { Dry Season } \\
\text { Wet Season } \\
\text { Dry Season } \\
\text { Wet Season } \\
\text { Dry Season } \\
\text { Wet Season } \\
\text { Dry Season } \\
\text { Wet Season } \\
\text { Dry Season } \\
\text { Wet Season } \\
\text { Dry Season } \\
\text { Wet Season } \\
\text { Dry Season } \\
\text { Wet Season } \\
\text { Dry Season } \\
\text { Wet Season }\end{array}$ & $\begin{array}{l}.402 \\
.203 \\
.214 \\
.087 \\
.484 \\
.496 \\
.183 \\
.214 \\
.092 \\
.173 \\
.232 \\
.090 \\
.452 \\
.302 \\
.308 \\
.100 \\
.139 \\
.134 \\
.300 \\
.131 \\
\end{array}$ & $\begin{array}{l}100 \\
100 \\
100 \\
100 \\
100 \\
100 \\
100 \\
100 \\
100 \\
100 \\
100 \\
100 \\
100 \\
100 \\
100 \\
100 \\
100 \\
100 \\
100 \\
100 \\
\end{array}$ & $\begin{array}{l}.000 \\
.000 \\
.000 \\
.057 \\
.000 \\
.000 \\
.000 \\
.000 \\
.035 \\
.000 \\
.000 \\
.045 \\
.000 \\
.000 \\
.000 \\
.015 \\
.000 \\
.000 \\
.000 \\
.000 \\
\end{array}$ & $\begin{array}{l}.246 \\
.753 \\
.750 \\
.971 \\
.249 \\
.146 \\
.922 \\
.665 \\
.946 \\
.947 \\
.780 \\
.963 \\
.091 \\
.545 \\
.461 \\
.970 \\
.905 \\
.959 \\
.463 \\
.961 \\
\end{array}$ & $\begin{array}{l}100 \\
100 \\
100 \\
100 \\
100 \\
100 \\
100 \\
100 \\
100 \\
100 \\
100 \\
100 \\
100 \\
100 \\
100 \\
100 \\
100 \\
100 \\
100 \\
100 \\
\end{array}$ & $\begin{array}{l}.000 \\
.000 \\
.000 \\
.028 \\
.000 \\
.000 \\
.000 \\
.000 \\
.000 \\
.001 \\
.000 \\
.006 \\
.000 \\
.000 \\
.000 \\
.021 \\
.000 \\
.003 \\
.000 \\
.005 \\
\end{array}$ \\
\hline
\end{tabular}




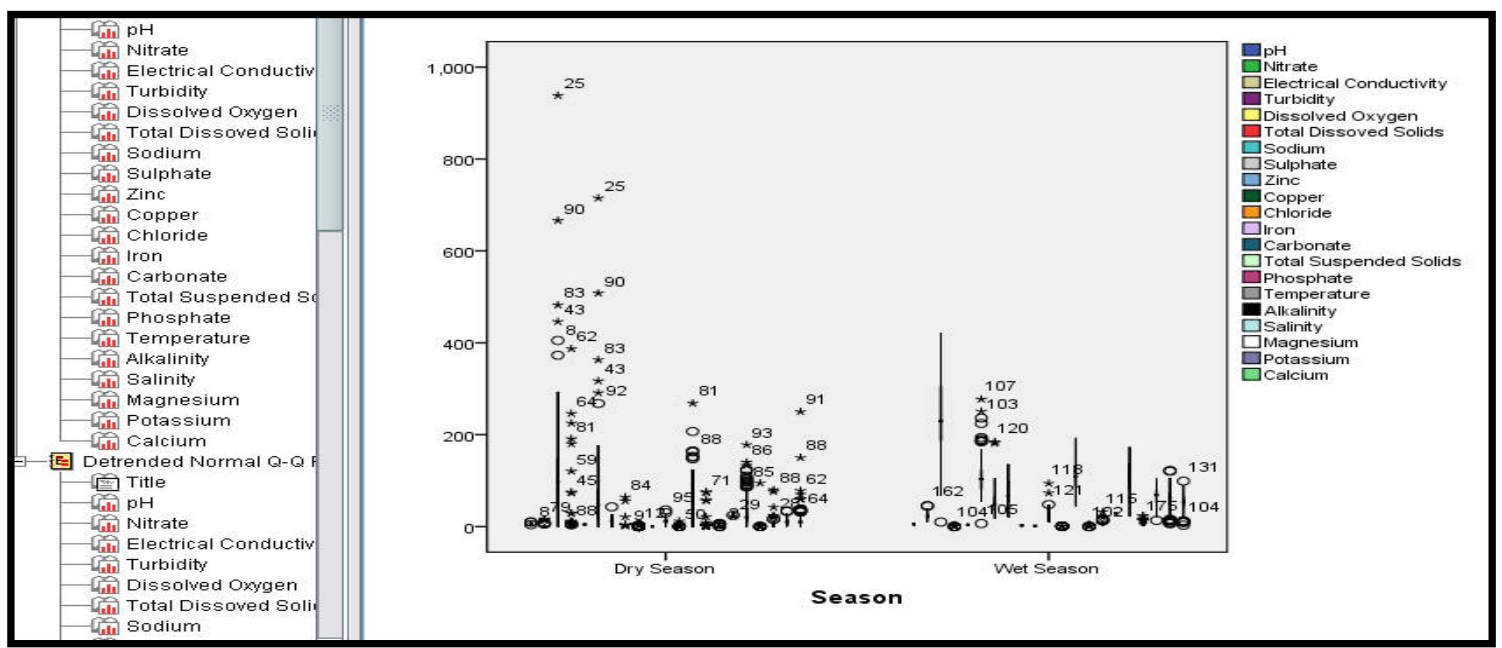

Figure 6: Seasonal box plot for assessing the presence of outliers

From the result of Table 3 and 4, it was observed that most of the dependent variables had p-value less than 0.05 based on Kolmogorov smirnov and Shapiro-wilk test. Since the calculated p-values based on Kolmogorov smirnov and Shapiro-wilk test are less than 0.05 , it was concluded that the dependent variables did not obey normality. Non-normally distributed dependent variables indicate the presence of seasonal variation. A further test of normality was done using the detrended normal quantile-quantile (Q-Q) plot presented in Figures $7 \mathrm{a}$ and $7 \mathrm{~b}$

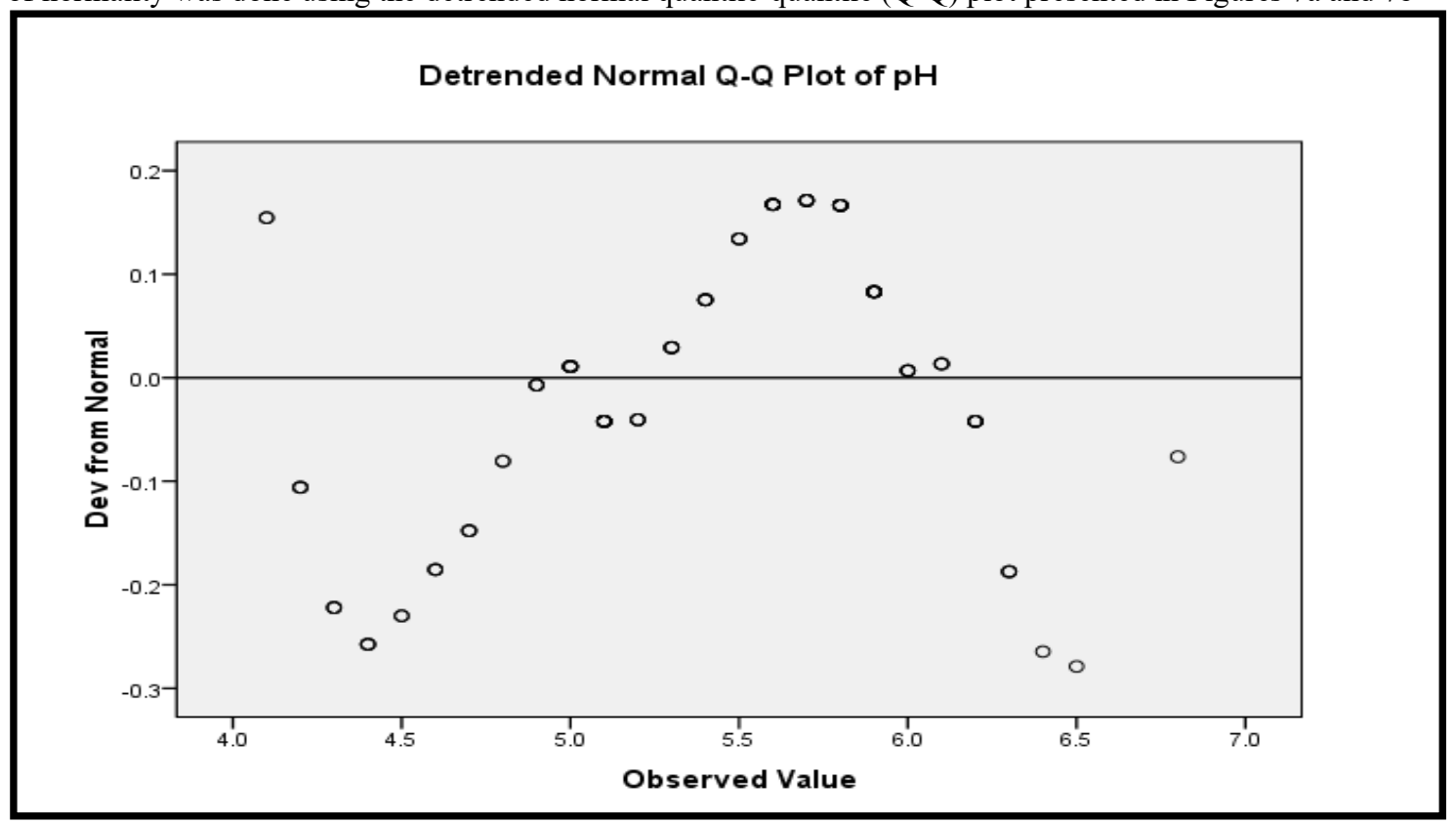

Figure 7a: Detrended normal Q-Q plot of pH 


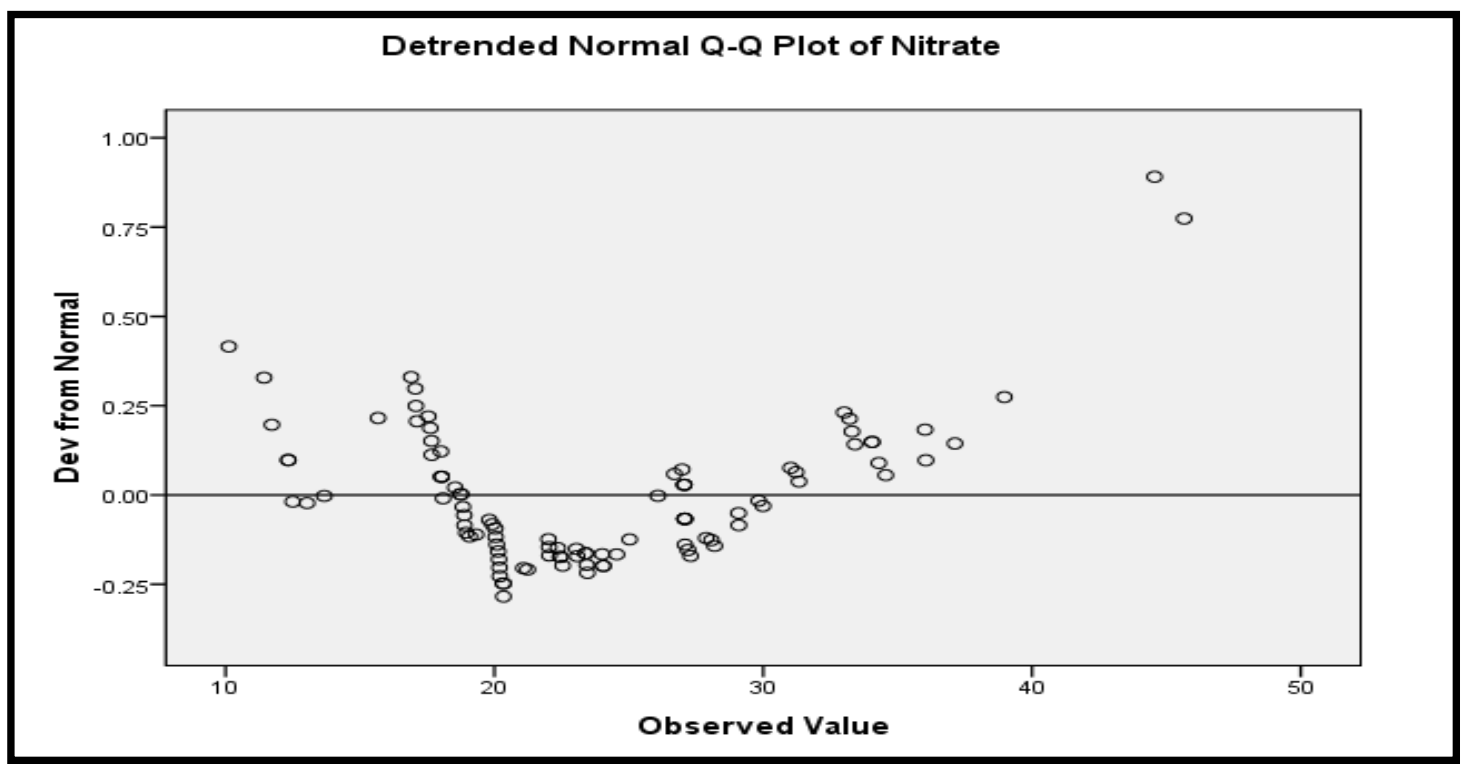

Figure 7b: Detrended normal Q-Q plot of nitrate

Since the dependented variables did follow the detrended normally distributed line, it was concluded that the variables are not normally distributed an indication that there is variation in the water quality parameters occassioned by season. On whether the dependent variables contain any form of outliers, the seasonal box plot presented in Figure 6 was employed. The presence of outlier is normally indicated with a square box or circle containing a number inside it. Since the circles in Figure 6 did not contain any number inside them, it was concluded that the dependent variables are devoid of possible outliers.

\subsubsection{Assessing the suitability of MANOVA based on multivariate outliers}

Multivariate alliance is usually calculated through a measure known as the Mahalanobis constant. If the maximum calculated value of the Mahalanobis constant is less than the critical value, then the assumption of multivariate outliers has not been violated. Therefore, if multivariate outliers have not been violated, then we can investigate the concept of seasonal variability using multivariate analysis of variance (MANOVA) otherwise, we must think of another statistical concept to track the presence of temporal variability. Results of the calculated Mahalanobis constant using regression analysis is presented in Figure 8

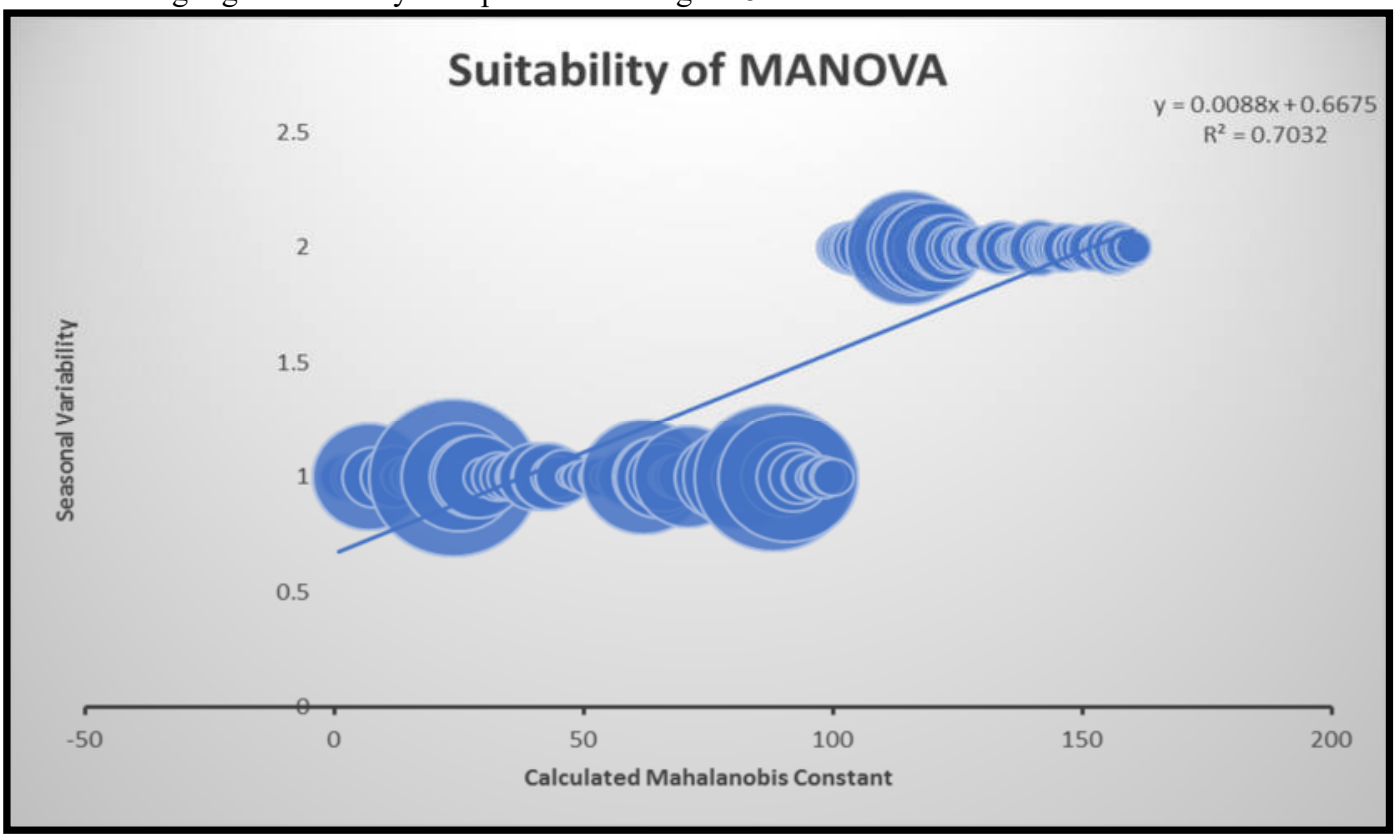

Figure 8: Variation of mahalanobis constant with season

With a coefficient of determination of 0.7032 , it was concluded that the maximum calculated value of Mahalanobis constant of 173.1431 was significant and can be employed to justify the use of multivariate analysis 
of variance in assessing the effect of seasonal variability. With ( $\mathrm{df}>10)$ the critical value of Mahalanobis constant was $(>29.59)$. Since $173.1431>29.590$, it was concluded that the assumptions of multivariate outliers have not been violated hence the use of multivariate analysis of variance to study the presence of seasonal variability is justified. To assess the degree of reliability of this claim, regression goodness of fit criteria was computed and presented in Table 5

Table 5: Computed regression goodness of fit criteria

\begin{tabular}{|c|c|c|c|c|c|c|c|}
\hline \multicolumn{6}{|c|}{ Model Summary } & & \\
\hline$\stackrel{\text { Mode }}{\perp}$ & $\mathrm{R}$ & R Square & \multicolumn{2}{|c|}{$\begin{array}{c}\text { Adjusted R } \\
\text { Square } \\
\end{array}$} & $\begin{array}{l}\text { Std. Error of } \\
\text { the Estimate }\end{array}$ & & \\
\hline 1 & $974=$ & 948 & & .942 & .120 & & \\
\hline \multicolumn{8}{|c|}{$\begin{array}{l}\text { a. Predictors: Constant, Calcium, Turbidity, Total Suspended Solids, Galinity, Total } \\
\text { Discoved Solids, Temperature, pH, Iron, Zinc, Fhosphate, Chloride, Allalinity, } \\
\text { Carbonate, Potassium, Godium, Copper, Dissolwed Oxygen, Nitrate, Sulphate, } \\
\text { Magnesium, Electrical Conductivity }\end{array}$} \\
\hline \multicolumn{8}{|c|}{ ANONA ${ }^{b}$} \\
\hline \multicolumn{2}{|l|}{ Madel } & \multicolumn{2}{|c|}{$\begin{array}{l}\text { Sum of } \\
\text { Squares }\end{array}$} & $\mathrm{df}$ & Mean Square & $\mathrm{F}$ & Big. \\
\hline \multirow[t]{3}{*}{1} & Regression & \multicolumn{2}{|c|}{47.424} & 21 & \multirow{3}{*}{$\begin{array}{r}2.258 \\
.014\end{array}$} & \multirow[t]{3}{*}{156.029} & \multirow[t]{3}{*}{$.000^{1}$} \\
\hline & \multirow{2}{*}{$\begin{array}{l}\text { Residual } \\
\text { Total }\end{array}$} & \multirow{2}{*}{\multicolumn{2}{|c|}{$\begin{array}{r}2.576 \\
50000\end{array}$}} & 178 & & & \\
\hline & & & & 199 & & & \\
\hline \multicolumn{8}{|c|}{$\begin{array}{l}\text { a. Predictors: (Constant), Calcium, Turbidity, Total Suspended Solids, Galinity, Total } \\
\text { Dissowed Solids, Temperature, pH, Iron, Zinc, Fhosphate, Chloride, Alkalinity, } \\
\text { Carbonate, Fotassium, Sodium, copper, Dissolwed Oxygen, Nitrate, Sulphate, } \\
\text { Magnesium, Electrical Conductivity }\end{array}$} \\
\hline \multicolumn{8}{|c|}{ b. Dependent Variable: Season } \\
\hline
\end{tabular}

The regression model is highly significant with a p-value $<0.05$. Coefficient of determination of 0.948 and Adjusted R-square value of 0.942 were good enuogh to conclude that the assumptions of multivariate outliers has not been violated which justify the use of MANOVA in this study. Since the assumption of multivariate outliers was not violated, multivariate analysis of variance was then applied to explain the seasonal variability in the quality of water at different sampling time (season). The following step by step analysis was employed to study the imaginative variance (seasonal variability in the water quality as a function of season)

\subsubsection{Descriptive Statistics}

Descriptive statistics was employed to check the difference in the mean and standard deviation of the sampling time (wet and dry season). Tables $6 \mathrm{a}$ and $6 \mathrm{~b}$ shows the descriptive statistics of the dependent variables 
Table 6a: Descriptive statistics of dependent variables

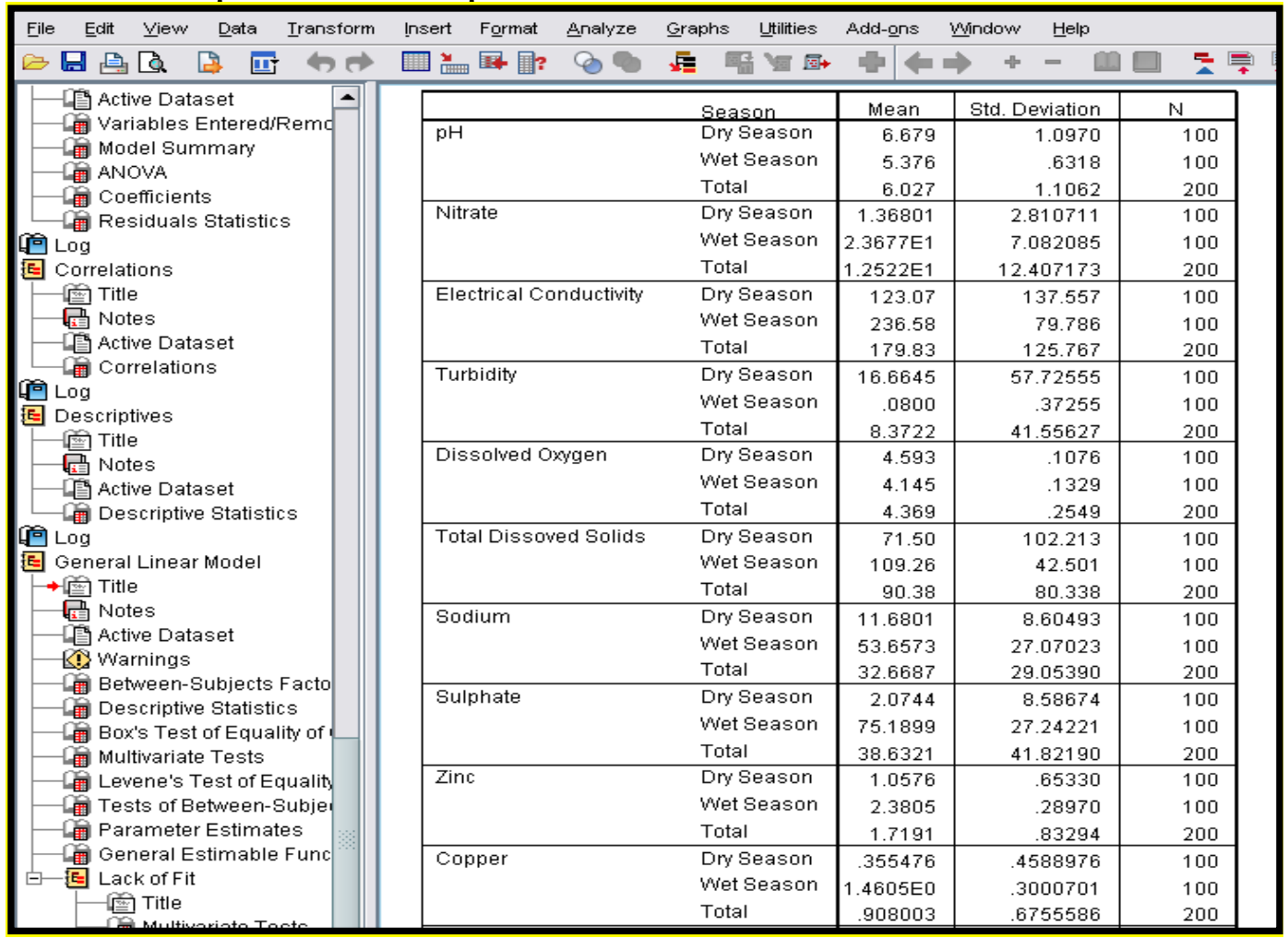

Table 6b: Descriptive statistics of dependent variables

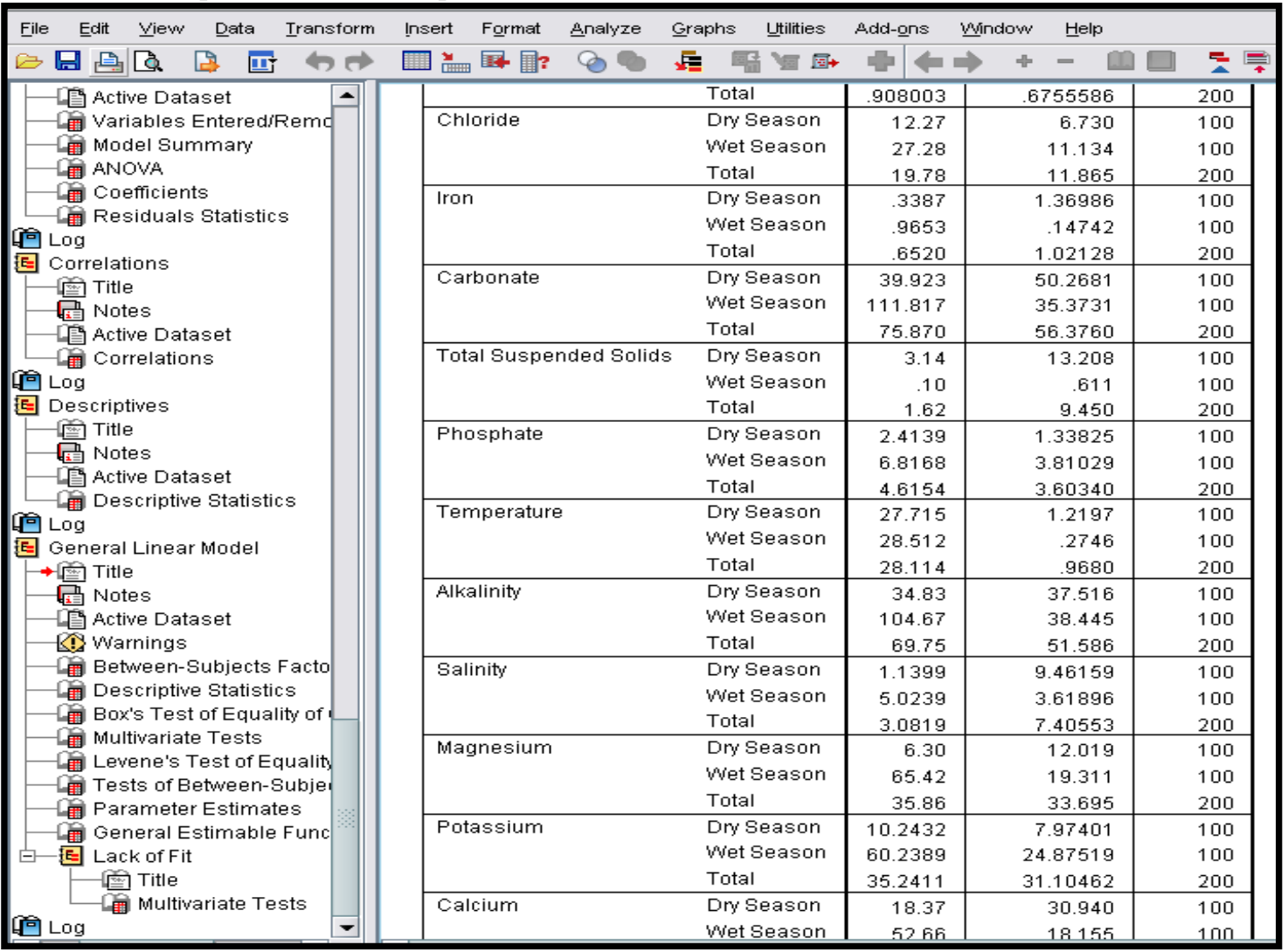


From the results of Tables $6 a$ and $6 b$, it was observed that there is a significant difference between the calculated mean and standard deviation of all the dependent variables as a function of sampling time (wet and dry season). For $\mathrm{pH}$, the mean \pm standard deviation during dry season was observed to be $6.679 \pm 1.0970$ and during wet season it was observed to be $5.376 \pm 0.6318$. For nitrate, the mean \pm standard deviation during dry season was observed to be $1.3601 \pm 2.810711$ and during wet season it was observed to be $2.3677 \mathrm{E} 1 \pm 7.082085$. For electrical conductivity (EC), the mean \pm standard deviation during dry season was observed to be $123.07 \pm 137.557$ and during wet season it was observed to be $236.58 \pm 79.786$. For turbidity, the mean \pm standard deviation during dry season was observed to be $16.6645 \pm 57.7256$ and during wet season it was observed to be $0.0800 \pm 0.37255$. For dissolved oxygen (DO), the mean \pm standard deviation during dry season was observed to be $4.593 \pm 0.1076$ and during wet season it was observed to be $4.145 \pm 0.1329$. The difference in the mean and standard deviation suggest the presence of imaginative variance which is seasonal variation occasioned by change in sampling time (dry and wet season).

\subsubsection{Box Test or Covariance Matrix}

In multivariate analysis of variance, we set out to test the null hypothesis that observed covariance matrix of all the dependent variables (water quality parameters) are equal across group (wet and dry season) that is there is no seasonal variation in the water quality parameters. If the calculated $p$-value is less than $0.05(p<0.05)$ we reject the null hypothesis and conclude that the assumption of equal covariance matrices across group has not been satisfied; an indication that seasonal variability exists among the group. The computed covariance matrix for the corrected model and season is presented in Tables $7 \mathrm{a}$ and $7 \mathrm{~b}$

Table 7a: Computed covariance matrix for corrected model

\begin{tabular}{|c|c|c|c|c|c|c|c|c|c|c|}
\hline 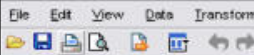 & 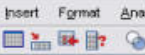 & 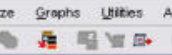 & $\begin{array}{l}\text { ans } y \text { indow } \\
4 \rightarrow+\end{array}$ & 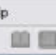 & 57 & & & & & \\
\hline $\begin{array}{l}\text { - Active Dataset } \\
\text { Variables EnterediReme }\end{array}$ & \multicolumn{10}{|c|}{ Tests of Between-Subjects Effects } \\
\hline $\begin{array}{l}\text { G Model Summary } \\
\text { OANOVA }\end{array}$ & & DenendentVariable & $\begin{array}{c}\text { Type III Sum } \\
\text { of Squares }\end{array}$ & or & Mean Square & $\mathbf{F}$ & sig. & $\begin{array}{l}\text { Partial Eta } \\
\text { Squared }\end{array}$ & $\begin{array}{l}\text { Noncent } \\
\text { Parameter }\end{array}$ & $\begin{array}{l}\text { Observed } \\
\text { Powere }\end{array}$ \\
\hline - Coefficients & Corrected Model & $\mathrm{pH}$ & $84.838^{2}$ & 1 & 84.838 & 105.878 & .000 & .348 & 105.878 & 1.000 \\
\hline Residuals statistics & & Nitrate & 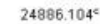 & 1 & 24886.104 & 857.313 & .000 & .812 & 857.313 & 1.000 \\
\hline 谓 Log & & Electrical Conductivaty & $644186.277^{\mathrm{d}}$ & 1 & 644186.277 & 50.949 & .000 & .205 & 50.949 & 1.000 \\
\hline 莤 Correlations & & Turbidity & $13752.416^{\circ}$ & 1 & 13752.416 & 8.254 & .005 & .040 & 8.254 & 816 \\
\hline Notes & & Dissolved Oxygen & $10.040^{\prime}$ & 1 & 10.040 & 687.165 & .000 & .776 & 687.165 & 1.000 \\
\hline Active Dataset & & Total Dissoved Solids & $71275.773^{\circ}$ & 1 & 71275.773 & 11.633 & .001 & .055 & 11.633 & .924 \\
\hline Correlations & & Sodium & $88104.274^{\circ}$ & 1 & 88104.274 & 218.393 & .000 & .524 & 218.393 & 1.000 \\
\hline 9 Log & & Sulphate & $267294.029^{\prime}$ & 1 & 267294.029 & 655.237 & .000 & .768 & 655.237 & 1.000 \\
\hline 固 Descriptives & & Zinc & 87.502 & 1 & 87.502 & 342.657 & .000 & .634 & 342.657 & 1.000 \\
\hline 皇 Titte & & Copper & $61.057^{\circ}$ & 1 & 61.057 & 406.196 & .000 & .672 & 406.196 & 1.000 \\
\hline 量 Notes & & Chiloride & $11258.847^{\prime \prime}$ & 1 & 11258.847 & 133.043 & .000 & .402 & 133.043 & 1.000 \\
\hline Active Dataset & & Iron & $19.635^{*}$ & 1 & 19.635 & 20.687 & .000 & .095 & 20.687 & 995 \\
\hline Descriptive Statistics & & Carbonate & $258437.340^{\circ}$ & 1 & 258437.340 & 136.807 & .000 & 408 & 136.807 & 1.000 \\
\hline 固 General Linear Model & & Total Suspended Solids & $461.752^{\circ}$ & 1 & 461.752 & 5.282 & .023 & .026 & 5.282 & 628 \\
\hline$\rightarrow$ 酋 Tite & & Phosphate & $969.294^{\circ}$ & 1 & 969.294 & 118.864 & .000 & .375 & 118.864 & 1.000 \\
\hline Notes & & Temperature & $31.745^{9}$ & 1 & 31.745 & 40.620 & .000 & .170 & 40.620 & 1.000 \\
\hline Active Dataset & & Alkalinity & $243892.448^{\circ}$ & 1 & 243892.448 & 169.048 & .000 & .481 & 169.048 & 1.000 \\
\hline \&is warnings & & Salinity & $754.272^{2}$ & 1 & 754.272 & 14.700 & .000 & .069 & 14.700 & .968 \\
\hline Between-Subjects Facto & & Magnesium & $174720.838^{\prime}$ & 1 & 174720.838 & 675.451 & .000 & .773 & 675.451 & 1.000 \\
\hline Descriptive Statistics & & Potassium & $124978.301^{*}$ & 1 & 124978.301 & 366.312 & .000 & 649 & 366.312 & 1.000 \\
\hline Boxs Te: & & Calcium & $58780.597 \mathrm{v}$ & 1 & 58780.597 & 91.353 & .000 & .316 & 91.353 & 1.000 \\
\hline
\end{tabular}

Table 7b: Computed covariance matrix based on seasonal variation

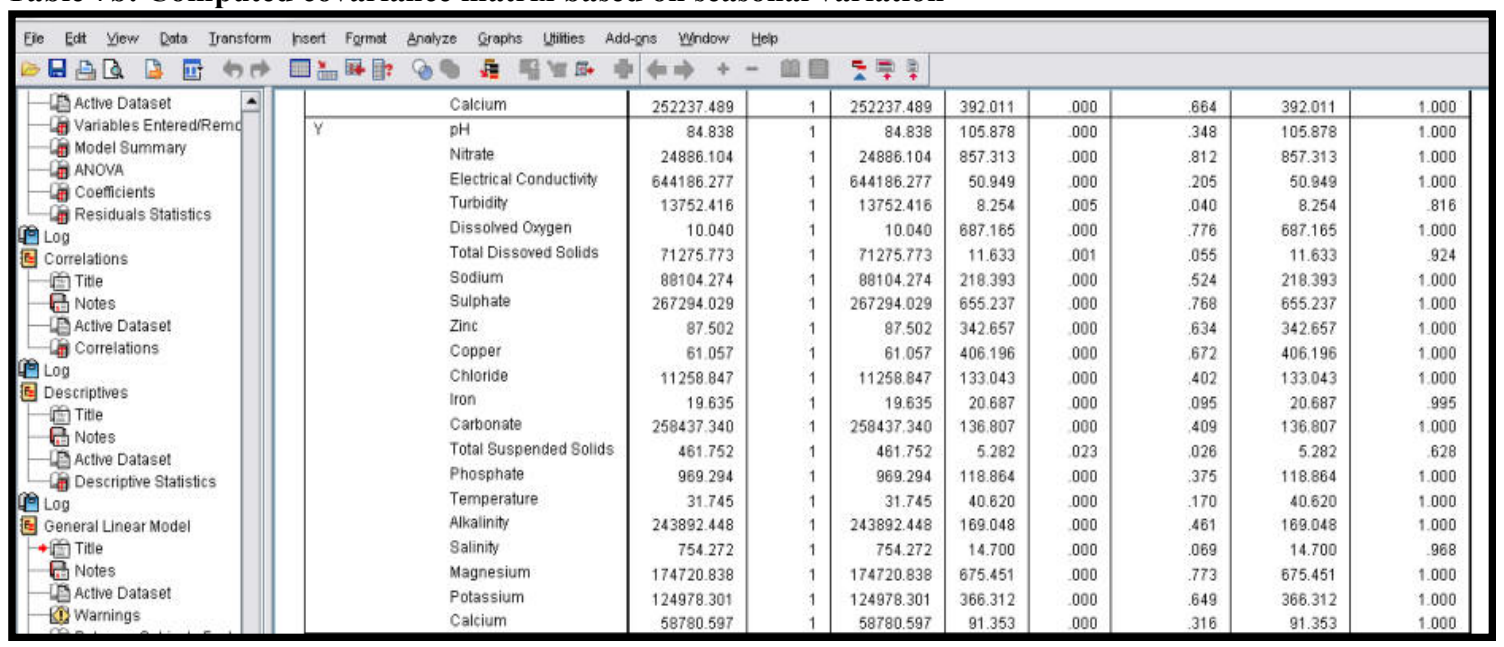

From the results of Tables $7 \mathrm{a}$ and $7 \mathrm{~b}$, it was observed that the computed significant values ( $\mathrm{p}$-value) for both the corrected model and season were less than 0.05; $(\mathrm{p}<0.05)$, hence the null hypothesis was rejected and it was concluded that the covariance matrix assumption was not satisfied. This means that the covariance matrices of the 
dependent variables are not equal across group an indication that seasonal variability exists. It was concluded based on the covariance matrix that the variation in the dependent variables is due to seasonal variability

\subsubsection{The Multivariate Test}

Different statistical method for computing the F-value for multivariate analysis of variance exits in literature. One of them is the Roy's largest root which is probably the most acceptable and also the most susceptible to deviation in the covariance matrix. The next is the Pillai's Trace followed by Wilk's Lambda. Pillai's Trace is the least sensitive to the violation of the assumption of covariance matrix hence it was selected for this study. Result of multivariate test statistics computed to study the effect of seasonal variability is presented in Table 8

From the result of Table 8, it was observed that the computed significant value (p-value) based on Roy's largest root, Wilk's Lambda, Hotelling's Trace and the Pillai's Trace was less than $0.05(\mathrm{p}=0.00)$ hence, the null hypothesis that the water quality parameters are the same for the two groups (wet and dry season) was rejected and it was conclude that seasonal variability actually exist. To calculate the percent variability that is accounted for due to seasonal variation, the partial Eta squared value of the Pillai's trace was employed. From the result of Table 4.11, the calculated partial Eta squared of the Pillai's trace was observed to be 1.00 which indicates $100 \%$ variability among the dependent variables occasioned by seasonal change.

In addition, when the null hypothesis of equal variance assumption is rejected, then the observed power function based on Pillai's trace must be between 0.9-1.00. From the result of Table 8, it was observed that the calculated power function based on Pillai's trace is 1.00 for both intercept and season. This validates the initial claim that seasonal variability exists between the dependent variables.

\subsubsection{Levene's Test of Equality of Error Variance}

If seasonal variability exists among the dependent variables then, the calculated error variance for all the dependent variables for wet and dry season must not be the same. To test the null hypothesis that the error variance of the dependent variables is equal across groups, Levene's test of equality of error variance was computed and presented in Table 9. From the result of Table 9, it was observed that the calculated p-value for most of the dependent variables were less than 0.05; an indication that the error variance of the dependent variables is not equal across group. Since the error variance of the dependent variables varies across group, it was concluded that seasonal variation exists between the dependent variables. Results of parameters estimates based on MANOVA is presented in Tables $10 \mathrm{a}$ and $10 \mathrm{~b}$

Table 8: Multivariate statistical table

\begin{tabular}{|c|c|c|c|c|c|c|c|c|c|c|}
\hline 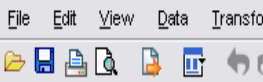 & 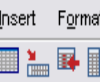 & $\begin{array}{l}\text { Analyze Graphs } \\
80 \text { 를 }\end{array}$ & $\begin{array}{l}\text { Litilties } \mathrm{Ac} \\
\mathrm{V} \text { 碀 }\end{array}$ & dd-ons Wino & $\begin{array}{l}\text { How Help } \\
+=-11\end{array}$ & 릇 & & & & \\
\hline 一 & & & & & Multiwar & Tests ${ }^{c}$ & & & & \\
\hline - Model Summary & Effect & & Value & $\mathrm{F}$ & Hypothesis df & Error df & Sig. & $\begin{array}{l}\text { Partial Eta } \\
\text { Squared }\end{array}$ & $\begin{array}{l}\text { Noncent. } \\
\text { Parameter }\end{array}$ & $\begin{array}{l}\text { Observed } \\
\text { Power" }\end{array}$ \\
\hline - & Intercept & Pillai's Trace & 1.000 & $2.159 \mathrm{E}^{\mathrm{a}}$ & 21.000 & 178.000 & .000 & 1.000 & 453347.175 & 1.000 \\
\hline C Residuals Statistics & & Wilks' Lambda & .000 & $2.159 E 4^{2}$ & 21.000 & 178.000 & .000 & 1.000 & 453347.175 & 1.000 \\
\hline Log & & Hotelling's Trace & $2.547 \mathrm{E} 3$ & $2.159 E 4^{2}$ & 21.000 & 178.000 & .000 & 1.000 & 453347.175 & 1.000 \\
\hline 圈 Correlations & & Roy's Largest Root & $2.547 \mathrm{E} 3$ & $2.159 \mathrm{E}^{\mathrm{a}}$ & 21.000 & 178.000 & .000 & 1.000 & 453347.175 & 1.000 \\
\hline 曾 Title & Y & Pillai's Trace & .948 & $1.560 \mathrm{E} 2^{\mathrm{a}}$ & 21.000 & 178.000 & .000 & .948 & 3276.617 & 1.000 \\
\hline Notes & & Wilks' Lambda & .052 & $1.560 \mathrm{E} 2^{\mathrm{a}}$ & 21.000 & 178.000 & .000 & .948 & 3276.617 & 1.000 \\
\hline D Correlations & & Hotelling's Trace & 18.408 & $1.560 \mathrm{E} 2^{\mathrm{a}}$ & 21.000 & 178.000 & .000 & .948 & 3276.617 & 1.000 \\
\hline Log & & Roy's Largest Root & 18.408 & $1.560 \mathrm{E} 2^{\mathrm{a}}$ & 21.000 & 178.000 & .000 & .948 & 3276.617 & 1.000 \\
\hline $\begin{array}{l}\text { Descriptives } \\
\text { Notives } \\
\text { Active Dataset }\end{array}$ & $\begin{array}{l}\text { a. Exac } \\
\text { b. Com } \\
\text { c. Desi }\end{array}$ & $\begin{array}{l}\text { statistic } \\
\text { uted using alpha = } \\
\text { n: Intercept }+Y\end{array}$ & & & & & & & & \\
\hline
\end{tabular}




\section{Table 9: Levene's Test Statistics}

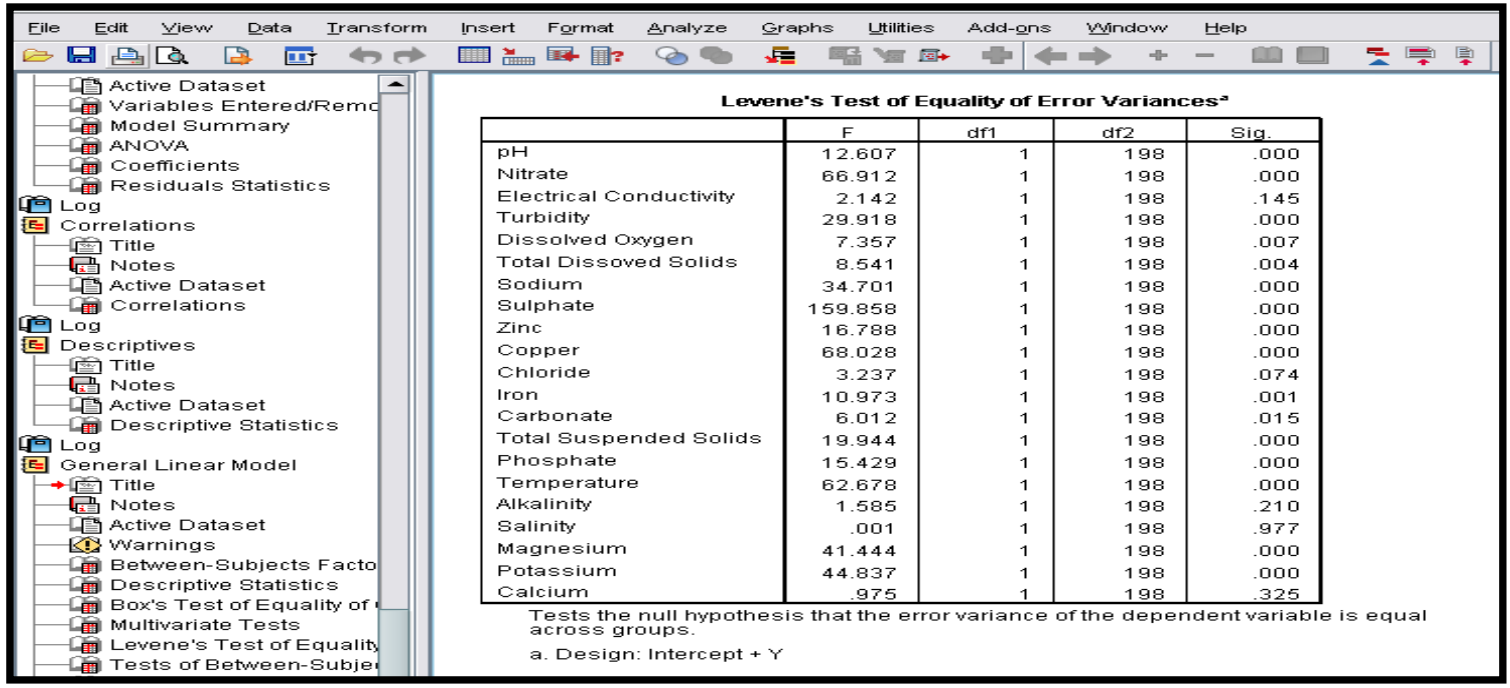

Table 10a: Parameter estimates using multivariate analysis of variance

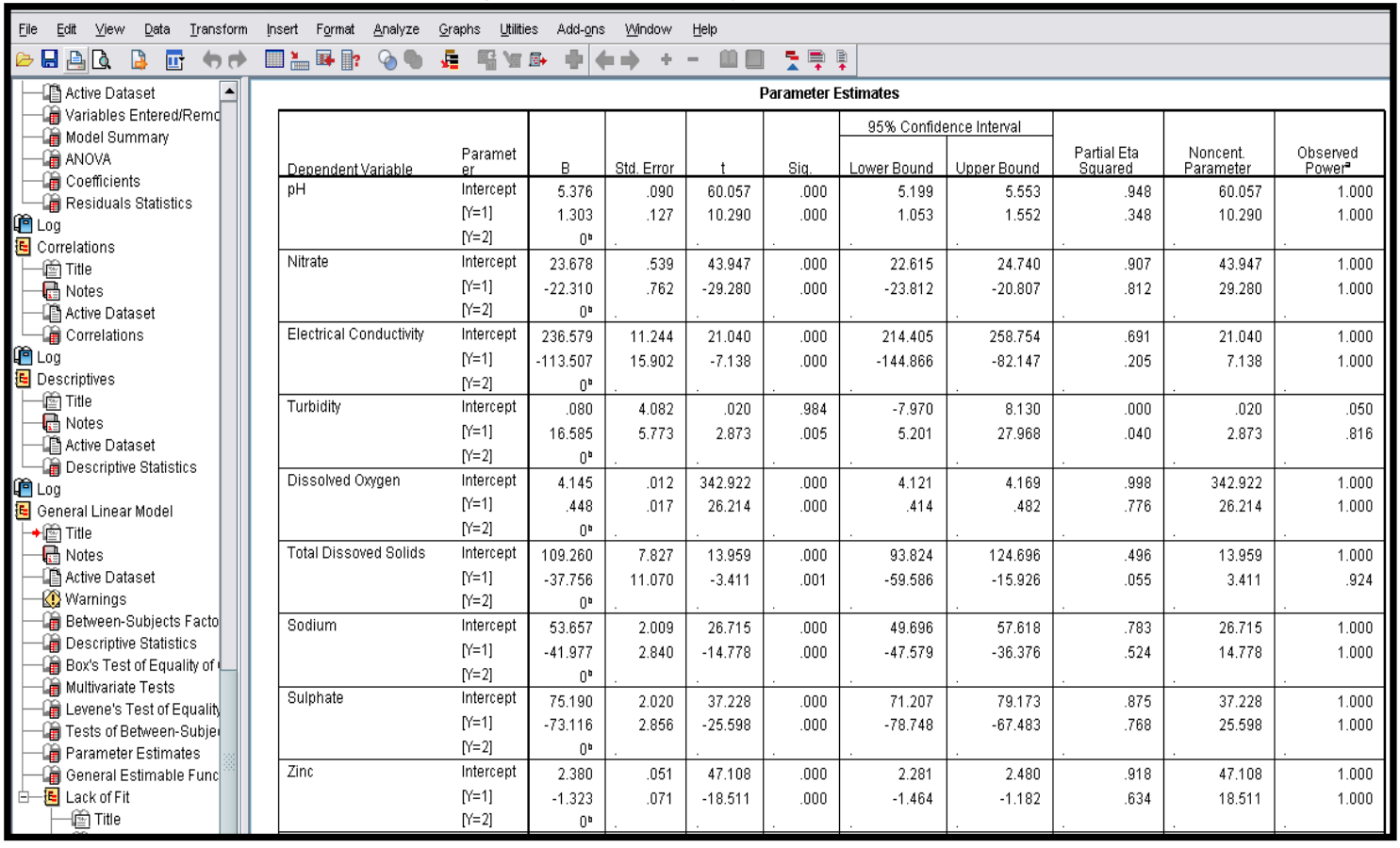


Table 10b: Parameter estimates using multivariate analysis of variance

\begin{tabular}{|c|c|c|c|c|c|c|c|c|c|c|c|}
\hline 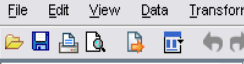 & 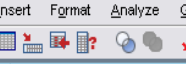 & raphs 步故 & $\begin{array}{l}s \text { Add-on } \\
\text { int }\end{array}$ & $\Rightarrow+$ & $\begin{array}{l}\text { Help } \\
-\quad \square[\end{array}$ & 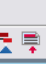 & & & & & \\
\hline - Active Dataset & Chloride & Intercept & 27.280 & .920 & 29.655 & .000 & 25.466 & 29.095 & .816 & 29.655 & 1.000 \\
\hline $\begin{array}{l}\text { Darla } \\
\text { Model Summary } \\
\text { ANOVA }\end{array}$ & & $\begin{array}{l}{[Y=1]} \\
{[Y=2]}\end{array}$ & $\begin{array}{r}-15.006 \\
0^{\mathrm{a}} \\
\end{array}$ & 1.301 & -11.534 & .000 & -17.571 & -12.440 & .402 & 11.534 & 1.000 \\
\hline Goefficients & Iron & Intercept & .965 & .097 & 9.909 & .000 & .773 & 1.157 & .331 & 9.909 & 1.000 \\
\hline $\begin{array}{l}\text { —苗 Residuals Statistics } \\
\text { Log }\end{array}$ & & $\begin{array}{l}{[Y=1]} \\
{[Y=2]}\end{array}$ & $\begin{array}{r}-627 \\
0^{\circ} \\
\end{array}$ & .138 & -4.548 & .000 & -.898 & -.355 & .095 & 4.548 & .995 \\
\hline 圈 Correlations & Carbonate & Intercept & 111.817 & 4.346 & 25.727 & .000 & 103.246 & 120.388 & .770 & 25.727 & 1.000 \\
\hline $\begin{array}{l}\text { 畺Title } \\
\text { 面 Notes }\end{array}$ & & $\begin{array}{l}{[Y=1]} \\
\Gamma Y=2]\end{array}$ & $\begin{array}{r}-71.894 \\
0^{\circ}\end{array}$ & 6.147 & -11.696 & .000 & -84.015 & -59.773 & .409 & 11.696 & 1.000 \\
\hline Andtive Dataset & Total Suspended Solids & Intercept & .101 & 935 & .107 & .915 & -1.743 & 1.944 & .000 & .107 & .051 \\
\hline Log & & $\begin{array}{l}{[Y=1]} \\
{[Y=2]}\end{array}$ & $\begin{array}{r}3.039 \\
0^{\circ} \\
\end{array}$ & 1.322 & 2.298 & .023 & .431 & 5.646 & .026 & 2.298 & .628 \\
\hline 譄 Title & Phosphate & Intercept & 6.817 & 286 & 23.872 & .000 & 6.254 & 7.380 & .742 & 23.872 & 1.000 \\
\hline $\begin{array}{l}\text { Notes } \\
\text { Active Dataset }\end{array}$ & & $\begin{array}{l}{[Y=1]} \\
\Gamma=2]\end{array}$ & $\begin{array}{r}-4.403 \\
0^{\circ}\end{array}$ & .404 & -10.902 & .000 & -5.199 & -3.607 & .375 & 10.902 & 1.000 \\
\hline Descriptive Statistics & Temperature & Intercept & 28.512 & .088 & 322.525 & .000 & 28.338 & 28.686 & .998 & 322.525 & 1.000 \\
\hline 圆 Log & & $\begin{array}{l}{[Y=1]} \\
{[Y=2]}\end{array}$ & $\begin{array}{r}-.797 \\
0^{\circ} \\
\end{array}$ & .125 & -6.373 & .000 & -1.043 & -.550 & .170 & 6.373 & 1.000 \\
\hline 曾 Title & Alkalinity & Intercept & 104.668 & 3.798 & 27.556 & .000 & 97.177 & 112.158 & .793 & 27.556 & 1.000 \\
\hline Active Dataset & & $\begin{array}{l}{[Y=1]} \\
{[Y=2]}\end{array}$ & $\begin{array}{r}-69.842 \\
0^{\circ}\end{array}$ & 5.372 & -13.002 & .000 & -80.435 & -59.249 & .461 & 13.002 & 1.000 \\
\hline B. Wetween-Subic & Salinity & Intercept & 5.024 & .716 & 7.014 & .000 & 3.611 & 6.436 & .199 & 7.014 & 1.000 \\
\hline $\begin{array}{l}\text { Descriptive Statistics } \\
\text { Dox's Test of Equality of }\end{array}$ & & $\begin{array}{l}{[\gamma=1]} \\
\gamma=2]\end{array}$ & $\begin{array}{r}-3.884 \\
0^{\circ} \\
\end{array}$ & 1.013 & -3.834 & .000 & -5.882 & -1.886 & .069 & 3.834 & .968 \\
\hline Thultivariate Tests & Magnesium & Intercept & 65.417 & 1.608 & 40.674 & .000 & 62.246 & 68.589 & .893 & 40.674 & 1.000 \\
\hline $\begin{array}{l}\text { Levene's Test of Equalit, } \\
\text { L Tests of Between-Subje }\end{array}$ & & $\begin{array}{l}{[Y=1]} \\
{[Y=2]}\end{array}$ & $\begin{array}{r}-59.114 \\
0^{\circ}\end{array}$ & 2.275 & -25.989 & .000 & -63.599 & -54.628 & .773 & 25.989 & 1.000 \\
\hline - Parameter Estimates & Potassium & Intercept & 60.239 & 1.847 & 32.613 & .000 & 56.596 & 63.881 & .843 & 32.613 & 1.000 \\
\hline 圈 Lack of Fit & & $\begin{array}{l}{[Y=1]} \\
{[Y=2]}\end{array}$ & $\begin{array}{r}-49.996 \\
0^{\circ} \\
\end{array}$ & 2.612 & -19.139 & .000 & -55.147 & -44.844 & .649 & 19.139 & 1.000 \\
\hline 哣 I Itie & Calcium & Intercept & 52.657 & 2.537 & 20.759 & .000 & 47.655 & 57.659 & .685 & 20.759 & 1.000 \\
\hline Log & & {$[Y=1]$} & -34.287 & 3.587 & -9.558 & .000 & -41.361 & -27.213 & .316 & 9.558 & 1.000 \\
\hline
\end{tabular}

\section{Conclusion}

The study was conducted to assess the quality of groundwater around the Niger Delta Basin Development Authority and evaluate the impact of seasonal variability (wet/dry season) on the groundwater quality. Results of the study have shown that a high degree of variability exist in the quality of groundwater collected from different locations within the study area. One of the major factors that are responsible for this variability is the influence of climate change occasioned by season. The study also demonstrated the potential of multivariate statistics as a tool for climatic variability studies. The content of this study is not completely exhaustive of the subject matter, but it has provided additional information to the already existing literatures on groundwater variability studies using statistical approach.

\section{References}

1. Alkarkhi AFM, Ahmad A, Ismail N, Easa, A and Omar K (2008): "Assessment of surface water through Multivariate Analysis.” Journal of Sustainable Development, Vol. 1(3), 27-33.

2. APHA (2005), Standard Methods for the Examination of Water and Wastewater, 18th edition, American Public Health Association Washington D C

3. Iyer, C. S; Sindhu, M; Kulkarni, S.G; Tambe, S.S and Kulkarni, B.D (2003): "Statistical analysis of the physico-chemica data on the coastal water of Cochin", Journal of Environmental Monitoring, vol. 5, 324-327.

4. Nwankwoala, H.O.; Eludoyin, O.S. and Obafemi, A.A. (2012): “Groundwater Quality Assessment and Monitoring Using Geographic Information Systems (GIS) In Port Harcourt, Nigeria." Ethiopian Journal of Environmental Studies and Management (EJEM) Vol. 5(4), 583-5967.

5. Shrestha S, Kazama F (2007). "Assessment of surface water quality using multivariate statistical techniques: A case study of the Fuji river basin, Japan.” Environ. Model. Software, vol. 22(4), 464-475.

6. Simeonov, V., Stratis J. A., Samara, C., Zahariadis, G., Voutsa D., Anthemidis A. Sofoniou M. and Kouimtzis T. (2003): Assessment of the surface water quality in Northern Greece, Water Resources Journal, vol. 37, 4119-4124.

7. Simeonov, V; Simeonova, P, and Tisitouridou, R., (2004): Chemometric quality assessment of surface waters: two case studies. Chem. Eng. Eco., 11(6), 449- 469

8. Sundara-kumar, K.; Sundara-kumar, P.; Ratnakanth Babu, M.J. and Hanumantha-Rao C. (2010), "Assessment and mapping of Ground water quality using Geographical Information Systems", International Journal of Engineering Science and Technology, Vol. 2(11), 6035-6046

9. World Health Organization (2003): "Manual of Basic Technique for a Health laboratory" World Health Organization, $2^{\text {nd }}$ Edition, Geneva. 